\title{
Therapeutic Efficacy Analysis of IncRNA NEAT1 Gene Knockout and Apoptosis Induction in Prostate Cancer Cell Line Using CRISPR/Cas9
}

\author{
Nastaran Haghighi $^{1}{ }^{\text {iD }}$, Abbas Doosti ${ }^{2 *}{ }^{*}$, Jafar Kiani $^{3}$ \\ ${ }^{1}$ PhD Student in Molecular Genetics, Department of Biology, Faculty of Basic Sciences, Shahrekord Branch, Islamic Azad \\ University, Shahrekord, Iran \\ ${ }^{2}$ Associate Professor, Biotechnology Research Center, Shahrekord Branch, Islamic Azad University, Shahrekord, Iran \\ ${ }^{3}$ Assistant Professor, Department of Molecular Medicine, Faculty of Advanced Technologies in Medicine, Iran University of \\ Medical Sciences, Tehran, Iran
}

* Corresponding Author: Abbas Doosti, Biotechnology Research Center, Shahrekord Branch, Islamic Azad University, Shahrekord, Iran. Email: abbasdoosti@yahoo.com

Received: 22.12 .2020 Accepted: 13.04 .2021

How to Cite this Article: Haghighi N, Doosti A, Kiani J. Therapeutic Efficacy Analysis of lncRNA NEAT1 Gene Knockout and Apoptosis Induction in Prostate Cancer Cell Line Using CRISPR/Cas9. Avicenna J Clin Med. 2021; 28(1): 49-58. DOI: $10.52547 /$ ajcm.28.1.49

\begin{abstract}
Background and Objective: Long non-coding ribonucleic acid (lncRNA) has been identified as an important gene regulator and prognostic marker in various cancers. The present study aimed to investigate the effects of Nuclear Paraspeckle Assembly Transcript1 (NEAT1) gene knockout using Clustered Regularly Interspaced Short Palindromic Repeats-associated Protein 9 (CRISPR/Cas9) in PC-3 cell line.

Materials and Methods: In this experimental study, recombinant plasmids carrying single guide RNA in the CRISPR system were designed and constructed. The prostate cancer PC3 cell lines were transfected by recombinant vectors, and apoptotic gene expression was evaluated using the quantitative polymerase chain reaction technique. Furthermore, annexin, MTT, and wound healing assays were applied for apoptosis, cell proliferation, and cell migration activities respectively.

Results: Knockout of NEAT1 gene using CRISPR/Cas9 technique caused significant changes in the expression of apoptosis-related genes in a way that the expression of P21, BCL2, and BIRC5 genes decreased, while the expression of P53 and BAX increased. In addition, in the treatment group, the rate of cell proliferation and migration was reduced compared to those in the control group. Moreover, an increase was observed in the apoptosis rate in genetically modified cells compared to the control group.

Conclusion: As an oncogene, NEAT1 plays an important role in tumorigenesis and its knockout reduces cell survival and migration and increases the apoptosis of cancer cells.
\end{abstract}

Keywords: CRISPR-Associated Protein 9, NEAT1 Long Non-coding RNA, Prostatic Neoplasms, PC-3 Cells 
do): $10.52547 / \mathrm{ajcm} \cdot 28.1 .49$

\title{
بررسى اثرات درمانى حذف IncRNA NEAT1 و القاى آيوڤِتوز در رده سلولى سرطان بروستات با استفاده از CRISPR/Cas9
}

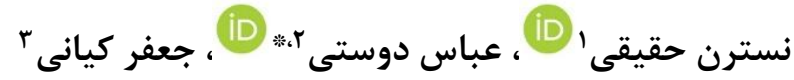 \\ ' دانشجوى دكترى زنتيك مولكولى، كروه زيستشناسى، دانشكده علوم يايه، واحد شهركرد، دانشعاه آزاد اسلامى، شهركرد، ايران

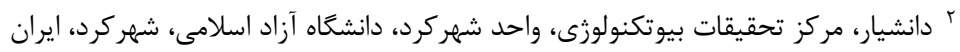

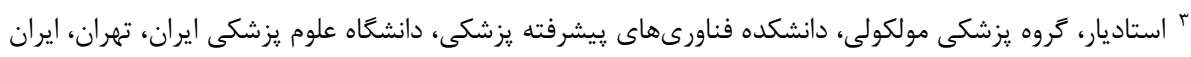 \\ * *ويسنده مسئول: عباس دوستى، مركز تحقيقات بيوتكنولوزى، واحد شهركرد، دانشعاه آزاد اسلامى، شهر كرد، ايران. \\ ايميل:ybbasdoosti@yahoo.com
}

\begin{tabular}{|c|c|}
\hline 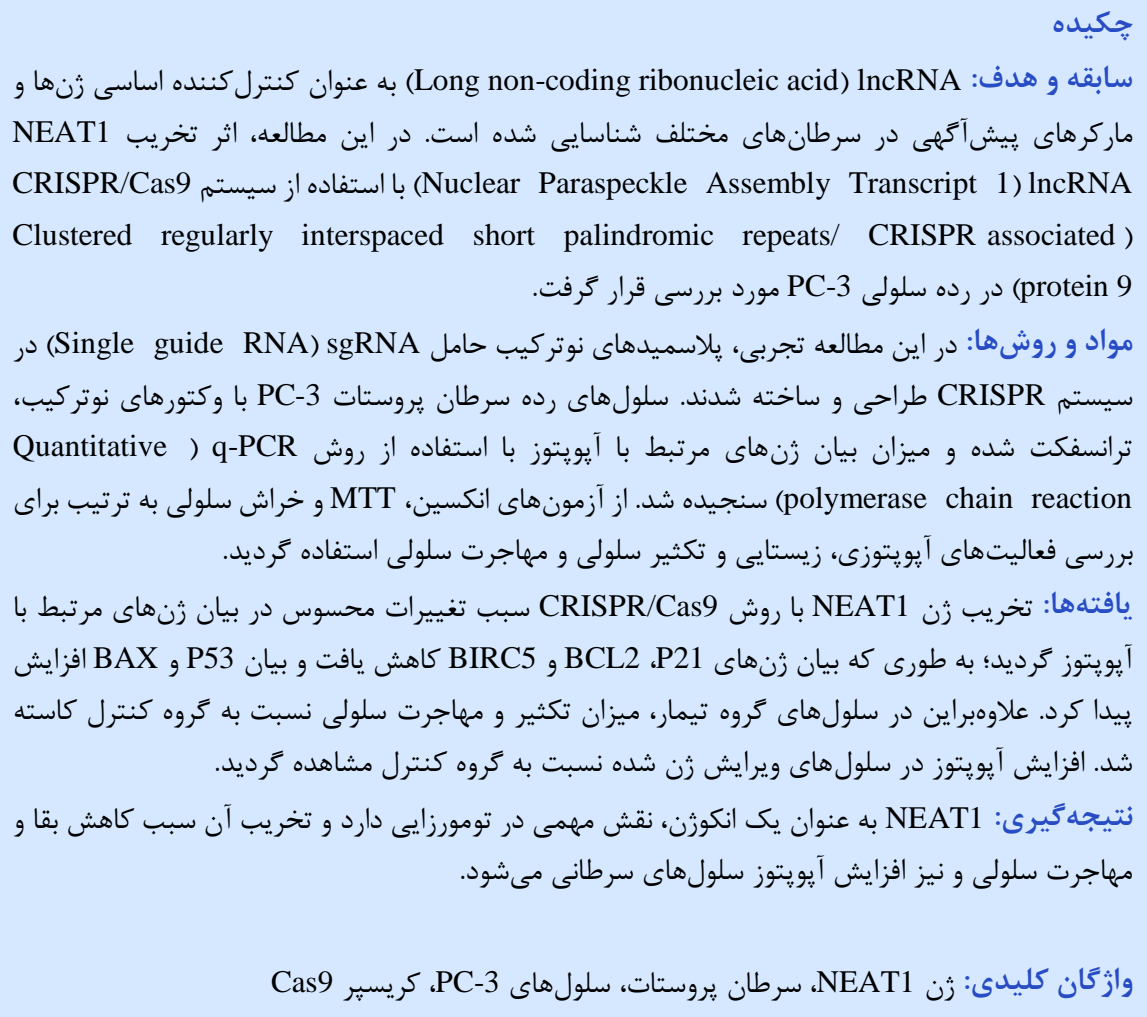 & 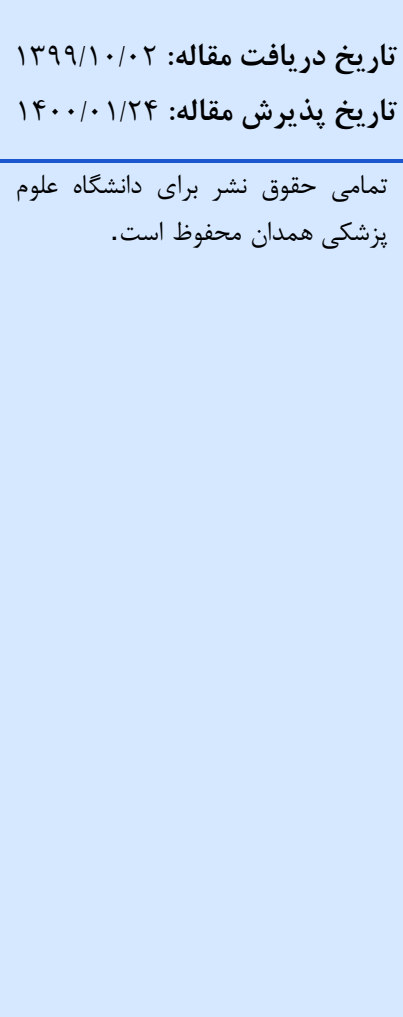 \\
\hline
\end{tabular}

سرطانها دارد؛ اما بر خلاف ساير سرطانها، توانايى تعيين و شناسايى زنهاى مربوط به آن محدود است [1]. تقريباً تمام

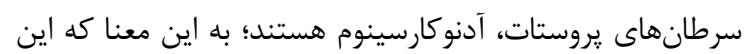

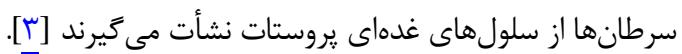

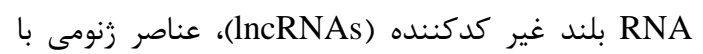

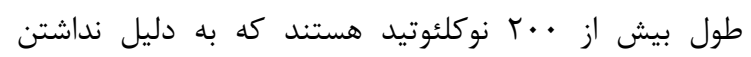

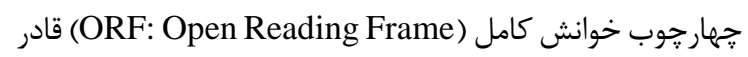
به توليد يروتئين نمىباشند. اين عناصر با تغيير ساختار يا اتصال

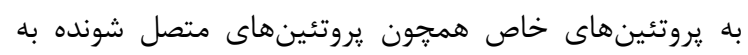

سرطان يروستات (Prostate Cancer) شايعترين سرطان در

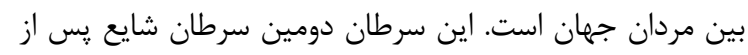

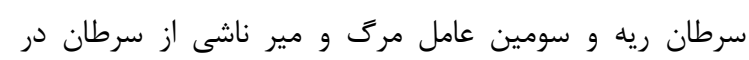
كشورهاى پِيشرفته مىباشد [1]]. افزايش سن و و نوع نزاد، عوامل

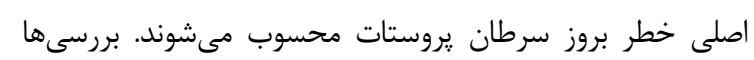

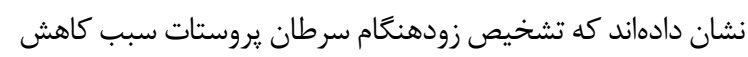

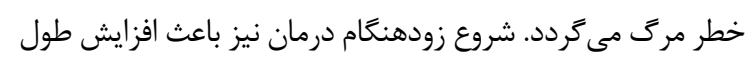

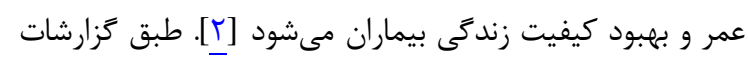

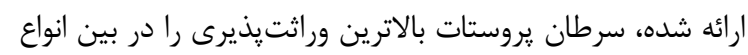


توقف جرخه سلولى و كاهش تكثير سلولهاى سرطان يروستات)

مىشود [1 [1].

با توجه به نقش انكورنى NEAT1 در اكثر سرطانها به به نظر

مىرسد كه با سر كوب اين عامل، بسيارى از ويزگَىهاى مربوط به به

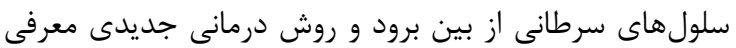

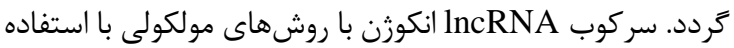
از RNA مداخلهَّ، RNA سنجاق سرى كوتاه، ميكرو RNA،

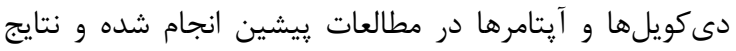
محسوسى در زمينه جلوكيرى از بيشرفت سلولهاى سرطانى

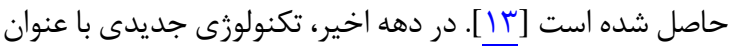
كريسير (CRISPR) معرفى شده است كه انقلابى را در زمينه

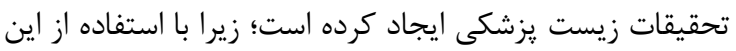

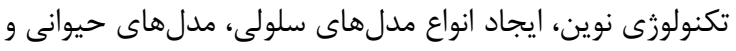

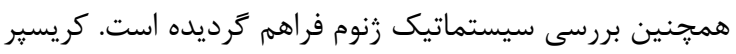
شامل تكر ارهاى ياليندرومى فاصلهدار منظم خوشهاى همر اه بازئن

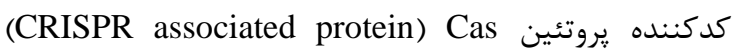

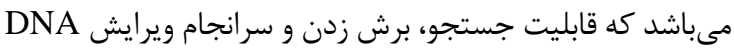

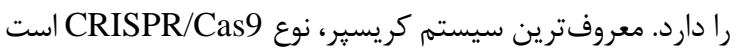

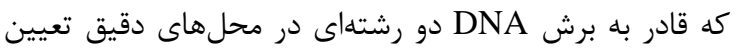

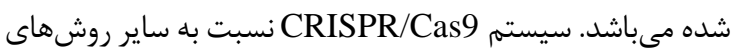

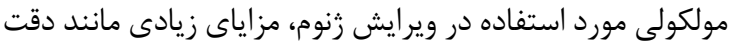

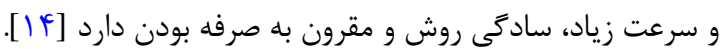

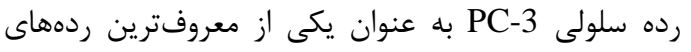

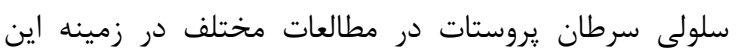

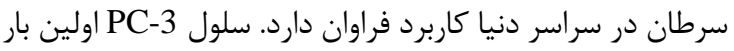

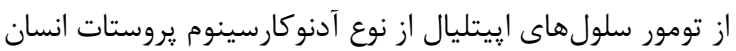

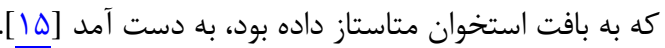

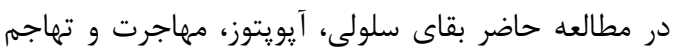

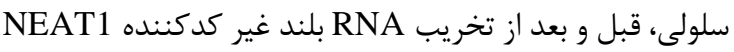

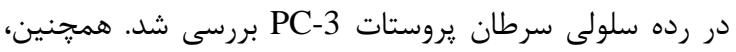

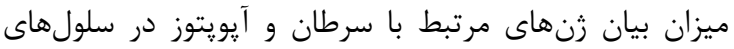

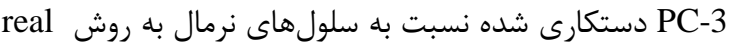
time PCR

\section{مواد و روشها مواد، باكترى، سلول و كيتها}

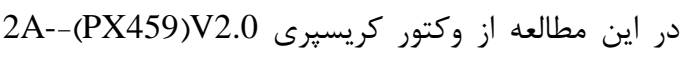

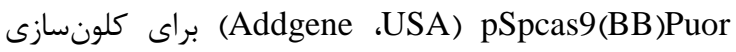
قطعات DNA بيان كننده RNA راهنما (sgRNA) استفاده شد. همجنين از باكترى E. coli سويه TOP10 براى تكثير يلاسميدهاى نوتركيب بهره كرفته شد. شايان ذكر است كه كيت

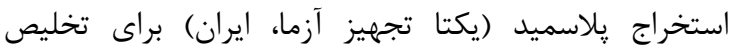

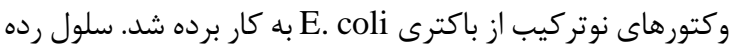
سرطان يروستات به نام PC-3 (بانك سلولى ايران) براى انجام

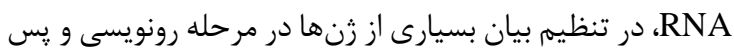

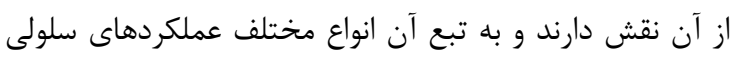

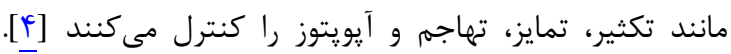

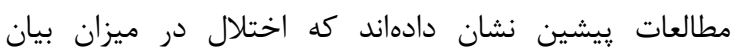

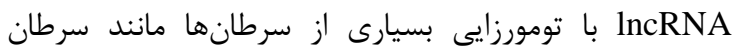
يروستات، معده، سرويكس، ريه، كبد و غيره در ارتباط هستند.

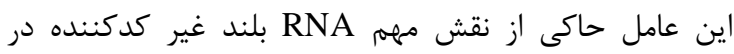

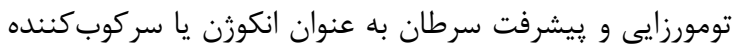

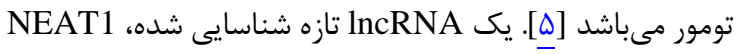

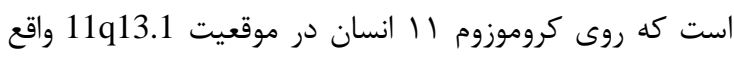

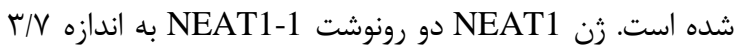

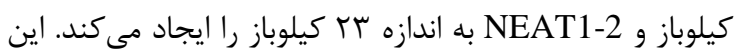
lncRNA

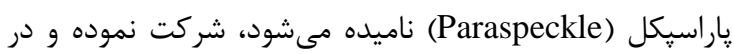

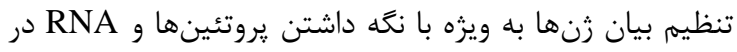

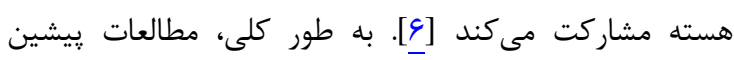

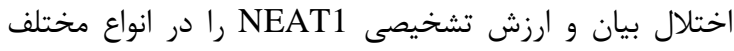

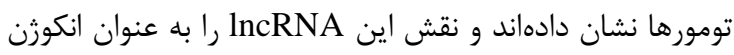
كه سبب بيشرفت تومور مىشود، تأييد نمودهاند [V]. افزايش

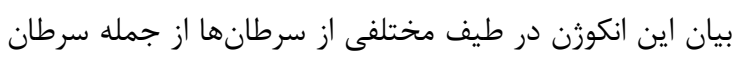

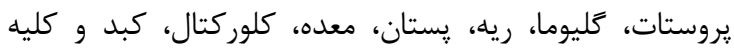

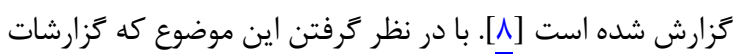

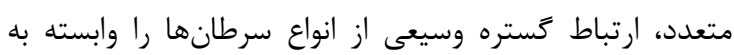

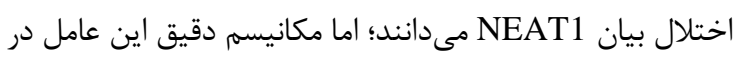

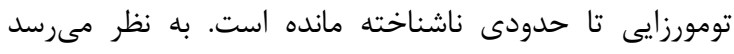

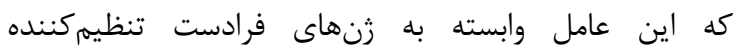

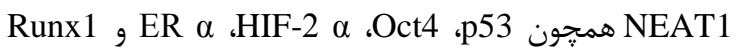

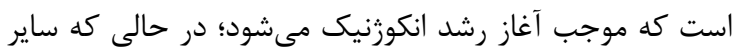

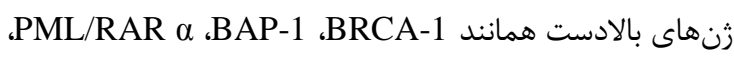
lncRNA موجب تنظيم منفى اين miR-548ar و هماندان miR-124

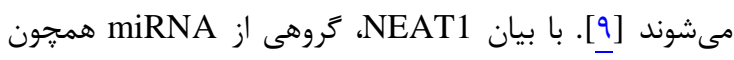
r

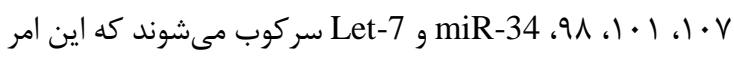
با تكثير سلولى، آيويتوزيس، تهاجم، مهاجرت، متاستازيس، انتقال

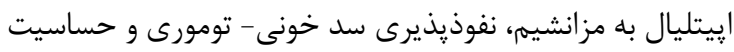

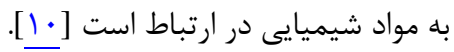

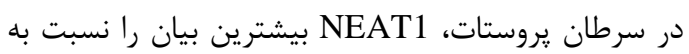

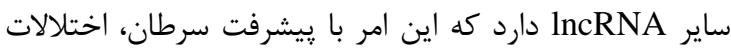

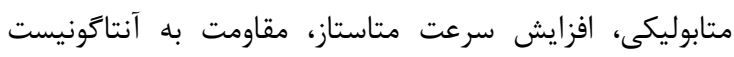

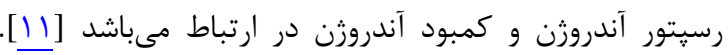
سركوب بيان زن NEAT1 به ترتيب با كاهش بيان فاكتور

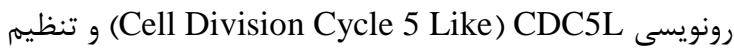
زن ARGN موجب بروز ويثز هاى فنوتييى قوى در سلول (از جمله افزايش تخريب Deoxyribonucleic acid) DNA)، 
اسپتروفتومترى توسط دستگًاه نانودراٍ (ترموفيشر، آمريكا) بررسى گرديد.

\section{كشت سلول و دستورزى سلولها}

رده سلولى سرطان يروستات PC-3 از بانك سلولى انستيتو

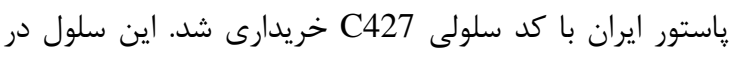

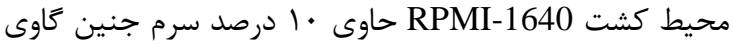
و آنتى بيوتيكهاى ينىسيلين (FBS: Fetal Bovine Serum) و استريتومايسين ( • • يكاى بينالمللى بر ميلىليتر ينىسيلين

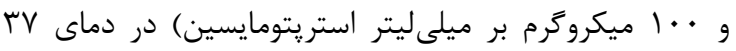

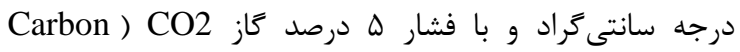
(dioxide) كشت داده شد. به منظور انجام ترانسفكشن (انتقال

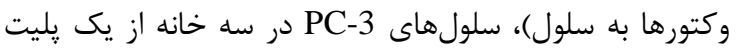

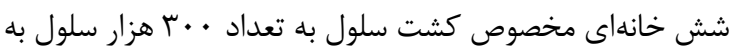

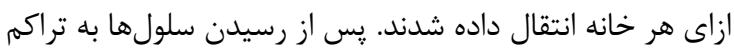

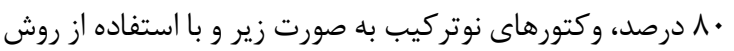

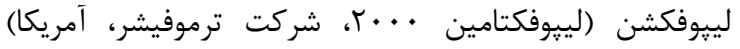
به هريك از خانهها منتقل گرديدند. در خانه اول، دو وكتور PX459-sgRNA1 و به صورت توأم به سلولهاى PC-3 منتقل شدند (كروه تيمار) و در خانه دوم،

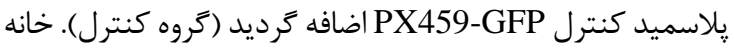

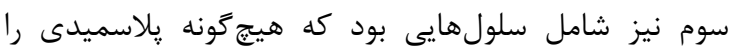

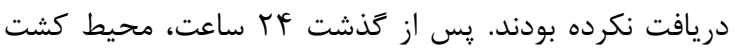

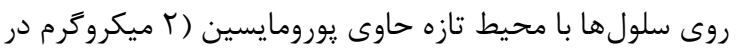

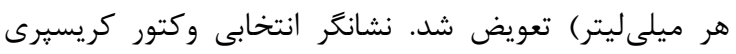

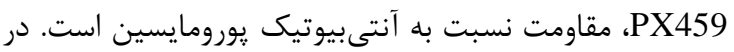

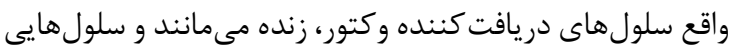

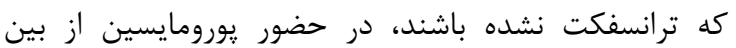
مىروند. براى اطمينان از صحت ترانسفكشن سلول ها با وكتور

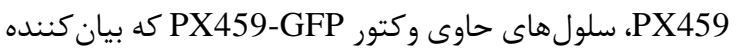
يروتئين سبز فلورسنت هستند، با ميكروسكوٍ فلورست

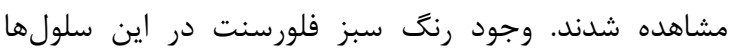

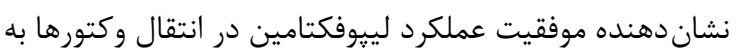
سلولهاى PC-3 مى باشد. براى بررسى انجام حذف رنى (ويرايش زنى) در خصوص رن

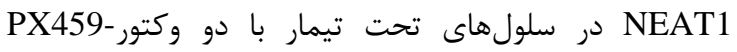
sgRNA2

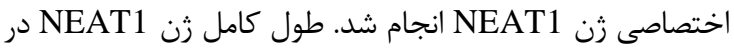

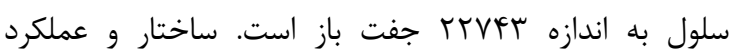

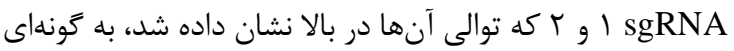
مىباشد كه موجب حذف يك قطعه سعس جفت بازى از از ابتداى

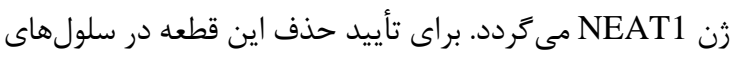
NEAT1-F/NEAT1-R1 دستكارى شده، به ترتيب ترايمرهاي

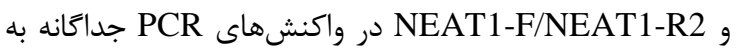

تجربيات ويرايش زنوم مورد استفاده قرار گرفت. از كيت استخراج از DNA DNA

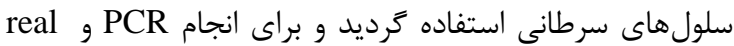
time PCR

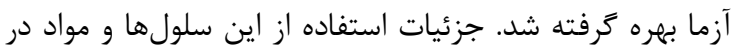
بخشهاى زير به تفصيل آمده است.

\section{طراحس، تكثير و استخراج وكتورنوتركيب}

در اين مطالعه تجربى، سيستم ويرايش رنى با استفاده از

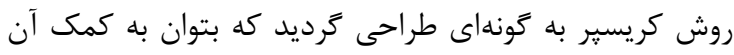

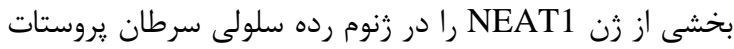
حذف كرد. براى اين منظور، دو توالى PC-3

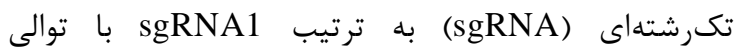
CCTACATAGCCACTAACATC و sgRNA2 با توالى توتئي GAAGTGTCTGTGCTGAGCCT طراحى شدند. Chop-Chop كه در صورت عملكرد صحيح سيستم كريسيرى، بخش بزرى آنى از

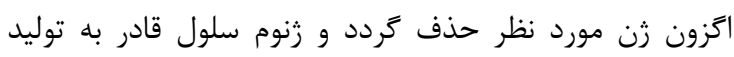

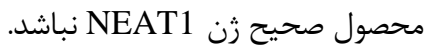
دو توالى sgRNA طراحى شده به صورت مجزا به دو يلاسميد pSpcas9(BB)2A-Puor-(PX459)V2.0 (Addgene ،USA) وارد شده و بدينترتيب وكتورهاى پيلاسميدى نوتركيب

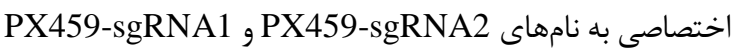
ايجاد كرديدند. در اين راستا و به منظور تأييد صحت وكتورهاى

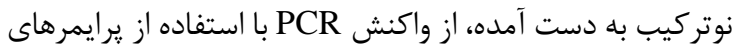

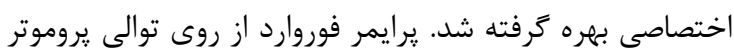

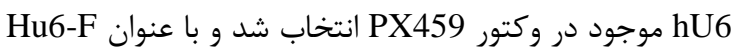

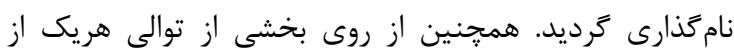

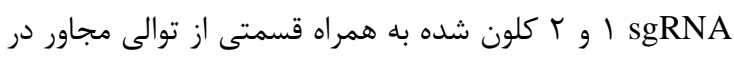

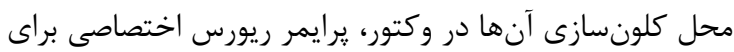

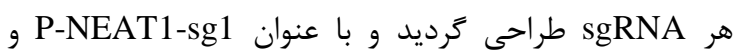
P-NEAT1-sg1 از جفت يرايمرهاى P-NEAT1-sg1/Hu6-F و و Pدول

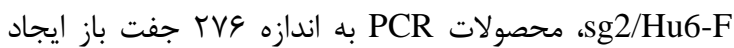
مىشود كه اين مهم نشاندهنده حضور هر sgRNA در وكتور مربوطه است. به منظور كنترل آزمايشات در تمامى مردم مراحل، از

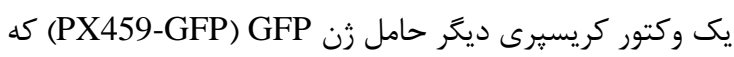
فاقد هر ₹ونه SgRNA بود، استفاده كرديد. به منظور تكثير وكتورهاى مذكور از باكترى E. coli سونه

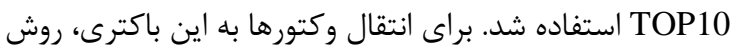
شيميايى (CaCl2) و شوك حرارتى مورد استفاده قرار كرفت.

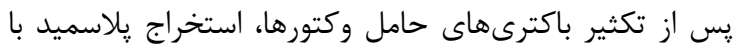

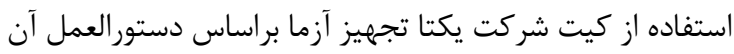

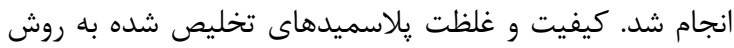


در دماى VY درجه سانتى كراد به مدت ا دقيقه انجام شد و تكثير

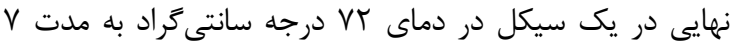

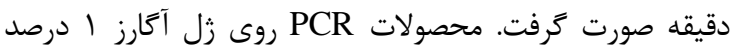

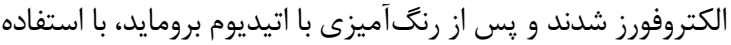

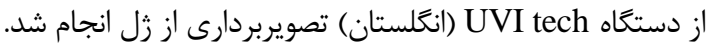

\section{استخراج RNA و سنتز DNA مكمل}

سلولها در هر دو گروه كنترل و تيمار با استفاده از RNA محلول RNX-Plus (سينا كلون، ايران) طبق دستورالعمل شر كت سازنده استخراج كرديد و DNA مكمل با استفاده از كيت

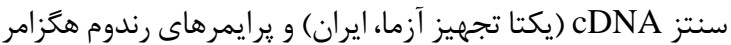
سنتز شد.

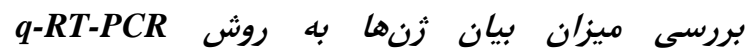
Quantitative reverse transcription polymerase)

\section{(chain reaction}

با توجه به اينكه RNA بلند غير كدكننده نظير NEAT1

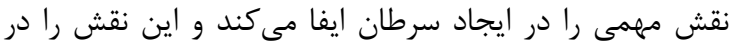

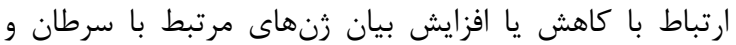

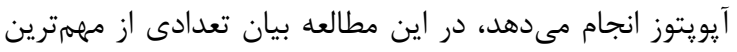

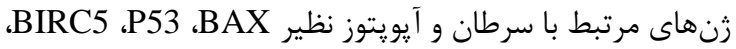
BCL2

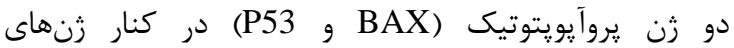

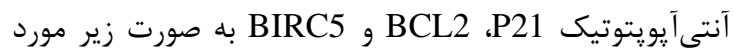
ارزيابى قرار گرفتند. با استفاده از يرايمرهاى اختصاصى اين زنها

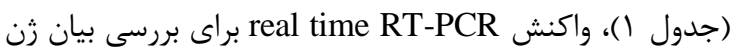

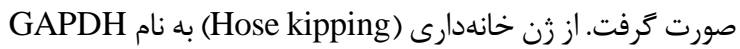
براى (Glyceraldehyde-3-Phosphate Dehydrogenase)
كار برده شدند. محصول PCR حاصل از فعاليت دو يرايمر F و

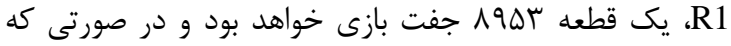

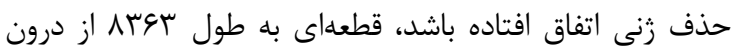

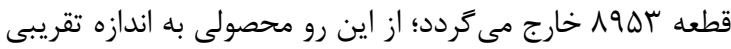
• ه9 جفت باز تشكيل خواهد شد كه نشاندهنده موفقيتآميز بودن ويرايش و تخريب زن NEAT1 مىباشد. لازم به توضيح است از آنجايى كه با انجام PCR معمولى و مرسوم، تكثير قطعهاى

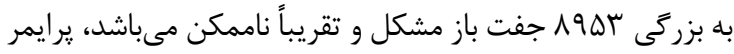

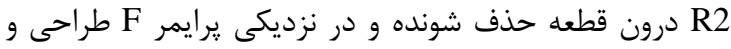

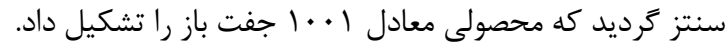

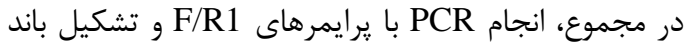
حدود • •9 جفت بازى نشاندهنده حذف قطعه هدف است؛ اما

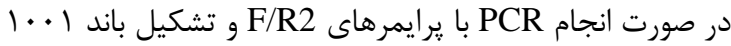
جفت بازى مشخص مى گردد كه حذف زن صورت نخرفته است؛

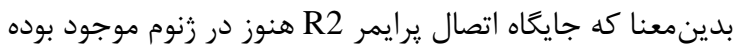
و ويرايش زنى به درستى صورت نيذيرفته است. براى انجام واكنشهاى PCR ذكر شده، ابتدا از سلولهاى هر گروه با استفاده از كيت استخراج DNA PC-3 ايران)، DNA زنومى سلولها تخليص كرديد. سيس هر واكنش

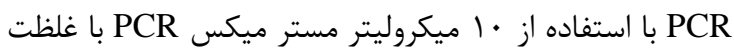
2X

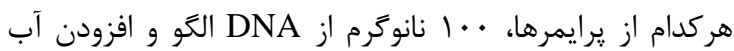

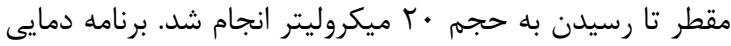

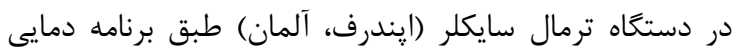
دناتوره شدن اوليه در يك مرحله در دماى له ده درجه سانتى

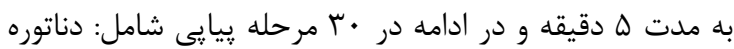

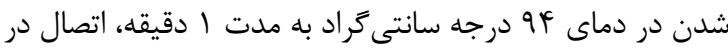

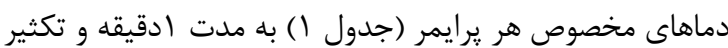

جدول ا: توالى برايمرهاى اختصاصى استفاده شده براى تكثير قطعات مورد نظر در واكنشهاى PCR-PCR و PCR

\begin{tabular}{|c|c|c|c|}
\hline ثن & 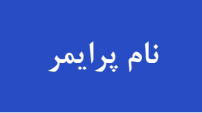 & 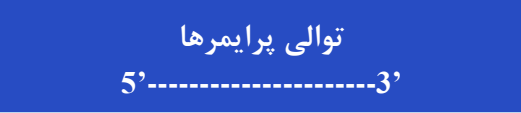 & 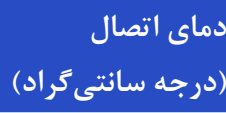 \\
\hline hU6 & Hu6-F & GAGGGCCTATTTCCCATGATT & gr \\
\hline PX549-sgRNA1 & P-NEAT1-sg1 & AAGACCGATGTTAGTGGCTATG & sT \\
\hline PX549-sgRNA2 & P-NEAT1-sg2 & AAGACCAGGCTCAGCACAGAC & sT \\
\hline NEAT1 & $\begin{array}{l}\text { NEAT1-R1 } \\
\text { NEAT1-F } \\
\text { NEAT1-R2 }\end{array}$ & $\begin{array}{l}\text { ACCTCGAACTCCTAGCCTCCTC } \\
\text { CTTTCATCTGCTTGTTCGTGCTC } \\
\text { CTTGTGCACTCTTGGTGAGAAC }\end{array}$ & \&T \\
\hline P53 & $\begin{array}{l}\text { P53-F } \\
\text { P53-R }\end{array}$ & $\begin{array}{l}\text { GTTCCGAGAGCTGAATGAGG } \\
\text { ACTTCAGGTGGCTGGAGTGA }\end{array}$ & sf \\
\hline $\mathrm{P} 21$ & $\begin{array}{l}\text { P21-F } \\
\text { P21-R }\end{array}$ & $\begin{array}{l}\text { GCTTCATGCCAGCTACTTCC } \\
\text { CCCTTCAAAGTGCCATCTGT }\end{array}$ & \&T \\
\hline BCL-2 & $\begin{array}{l}\text { BCL-2-F } \\
\text { BCL-2-R }\end{array}$ & $\begin{array}{c}\text { GACGACTTCTCCCGCCGCTAC } \\
\text { CGGTTCAGGTACTCAGTCATCCAC }\end{array}$ & $\Delta 9$ \\
\hline BIRC5 & $\begin{array}{l}\text { BIRC5-F } \\
\text { BIRC5-R }\end{array}$ & $\begin{array}{c}\text { TGCCTGGCAGCCCTTTC } \\
\text { CCTCCAAGAAGGGCCAGTTC }\end{array}$ & \&T \\
\hline BAX & $\begin{array}{l}\text { BAX-F } \\
\text { BAX-R }\end{array}$ & $\begin{array}{c}\text { ACTTCAGGTGGCTGGAGTGA } \\
\text { AGGTCTTTTTCCGAGTGGCAGC }\end{array}$ & 9) \\
\hline GAPDH & $\begin{array}{l}\text { GAPDH-F } \\
\text { GAPDH-R }\end{array}$ & $\begin{array}{l}\text { GCCAAAAGGGTCATCATCTCTGC } \\
\text { GCCAAAAGGGTCATCATCTCTGC }\end{array}$ & sq \\
\hline
\end{tabular}




\section{سنجش مهاجرت سلولى}

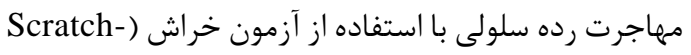

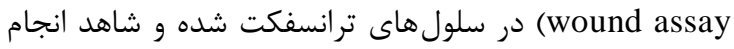

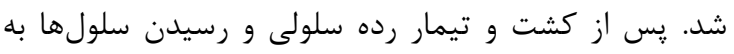

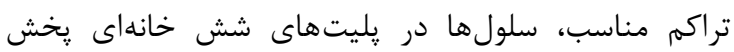

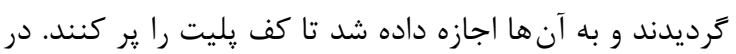

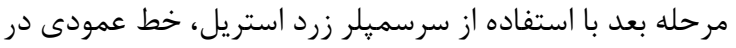

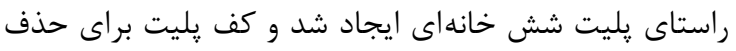

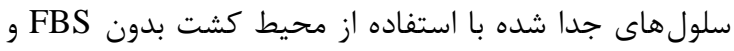

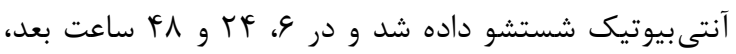

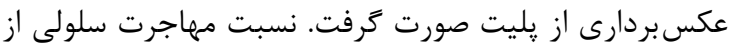

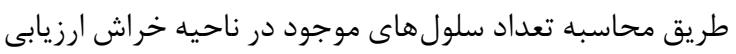
كرديد [11]

$$
\text { آناليزهاى آمارى }
$$

تمامى آزمونهاى انجام شده به صورت سه بار تكرار بودند

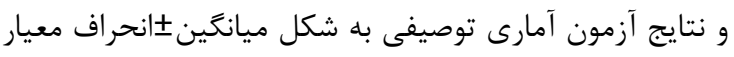

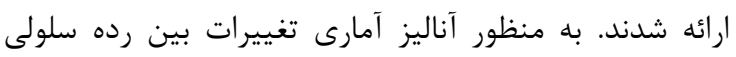

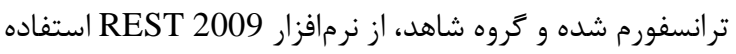

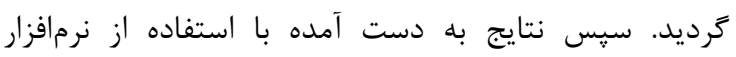
تجزيه و تحليل شدند. براى بررسى وجود يا عدم

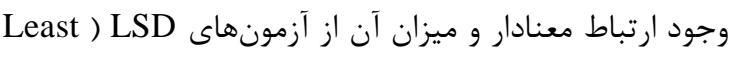
و Independent t-test (significant difference

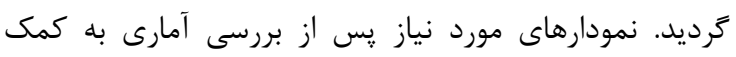

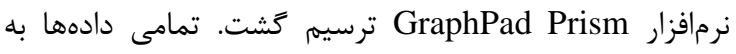
صورت ميانگين

$$
\text { از (ه< (P<) در نظر كرفته شد. }
$$

\section{يافته ها}

\section{تأ ييد فرايند كلونينت و ساخت وكتور نوتركيب}

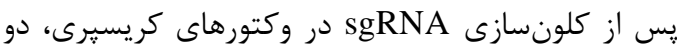

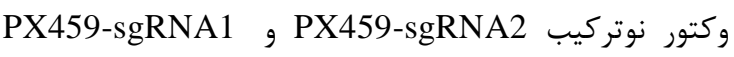
ايجاد شدند. انجام PCR با يرايمرهاى اختصاصى هريك از sgRNA همراه يرايمر فوروارد Hu6-F روى وكتور نوتركيب مربوطه

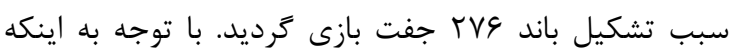

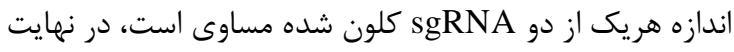

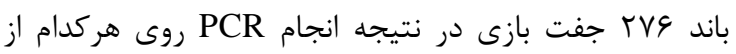

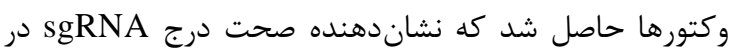
وكتورهاى كريسيرى مى باشد.

\section{تأييد صحت لييوفكشن}

در شرايط يكسان، سلولهاى PC-3 به دو گروه تقسيم شدند.

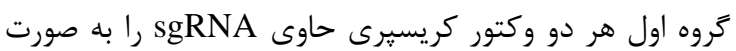

نرمالسازى دادههاى real time PCR بهره گرفته شد. در هر

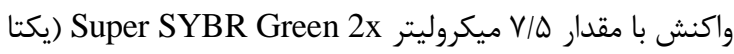

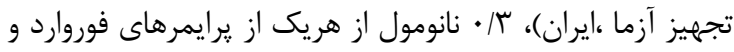

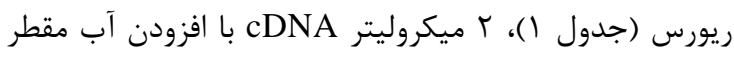

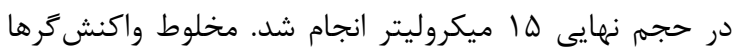

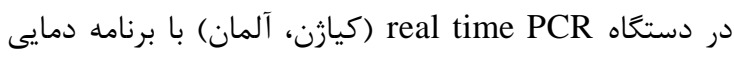
يك مرحله Yq درجه سانتى

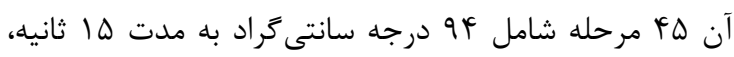

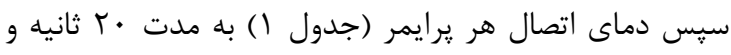

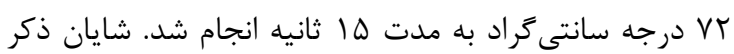

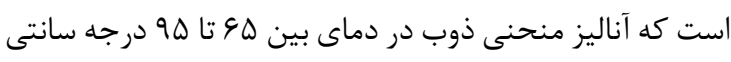

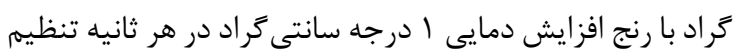

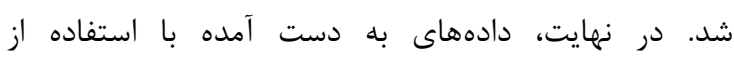

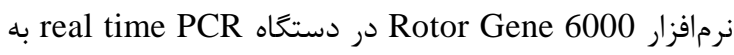
روش نرمار

\section{آزمون انكسين و بررسى آيويتوز}

با بتفاده از كيت Annexin-V-FITC/Propidium iodide (ترموفيشر، آمريكا) و طبق يروتكل مربوطه، ميزان آيويتوز و نكروز در هر دو تروه سلول ويرايش شده به كمك سيستم كريسيرى و و

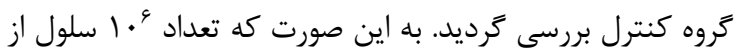

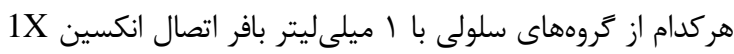
مخلوط گرديد. سيس مقدار ه ه ه (Annexin-V binding buffer)

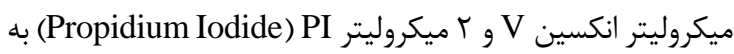

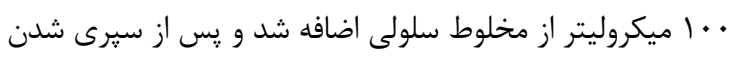

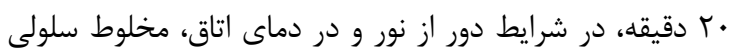

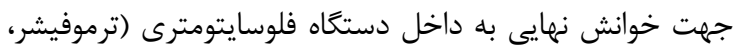

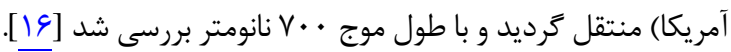

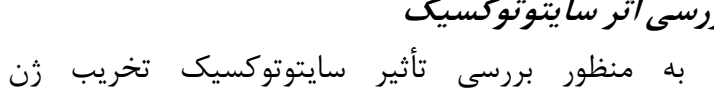

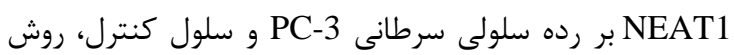

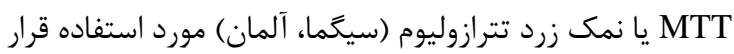
كرفت. به طور خلاصه، به سلولهاى تيمار شده موجود در جاهكها پس از انكوباسيون در شرايط دمايى و فشارى مذكور،

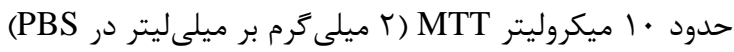
اضافه گرديد و به مدت جهيار ساعت انكوبه شد تا كريستالهاى

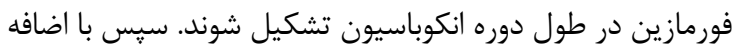

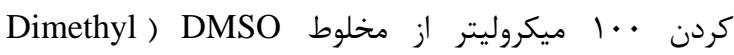

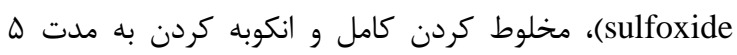
دقيقه، جذب نورى (OD: Optical density) هريك از خاهك ونها

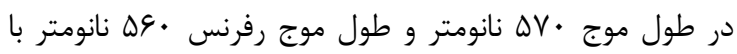

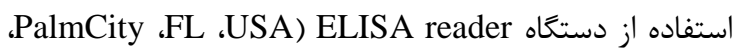
[IV] عزارش شد (Awareness Technology 


\section{تغيير بيان ثن هاى مرتبط با آبويتوز}

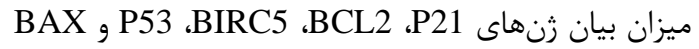

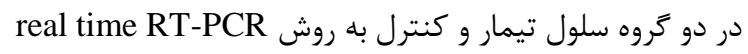

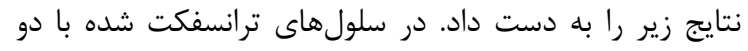

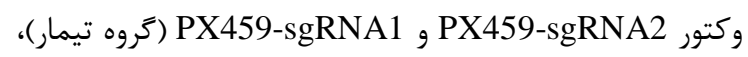

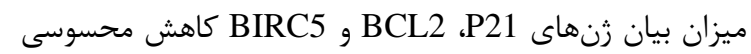

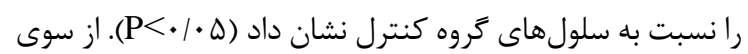

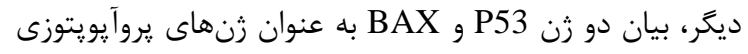

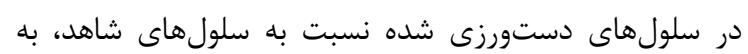

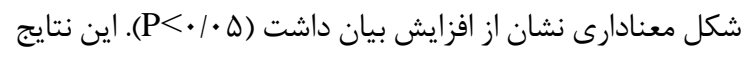

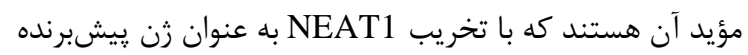

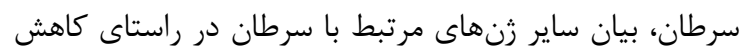

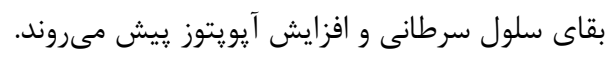

\section{نتا يج بررسى آيويتوز}

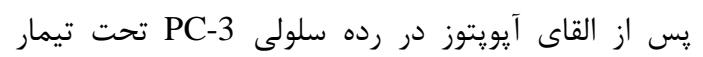

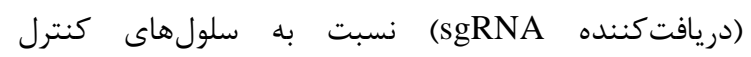

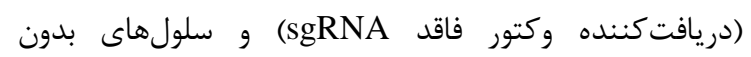
دستكارى (بدون وكتور)، درصد سلولها در مركاف مراحل مختلف

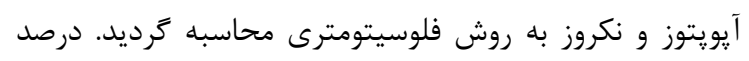

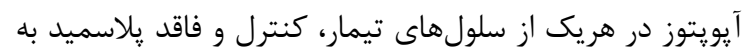

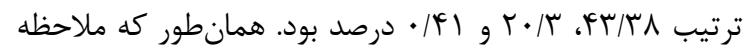

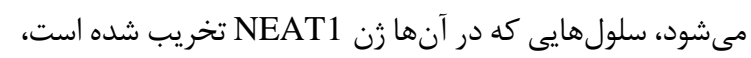

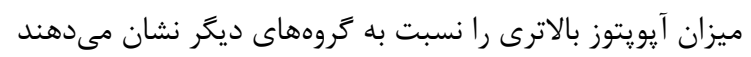

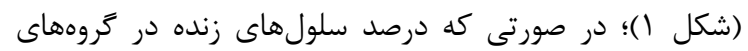

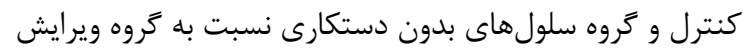
زن شده، بسيار بيشتر است.

\section{نتايج MTT}

نتايج آزمون MTT نشاندهنده كندى تكثير سلولهاى
همزمان دريافت كرد و كروه دوم وكتور فاقد sgRNA و حاوى يروتئين سبز فلورسنت (GFP: Green fluorescent protein)

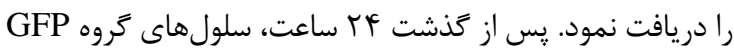

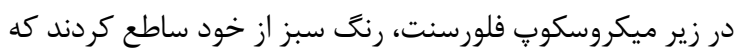

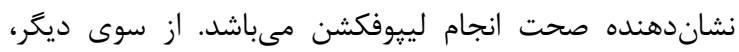

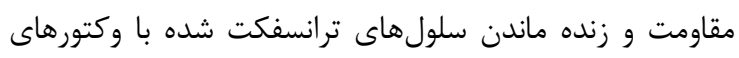

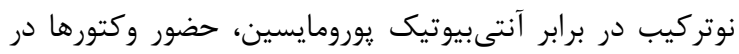

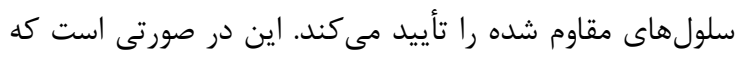

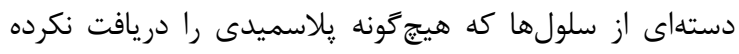

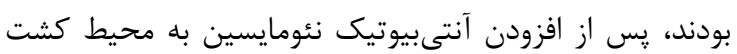

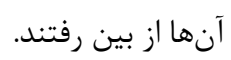

\section{نتا يج ويرايش ثزوم سلولى}

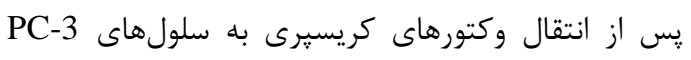

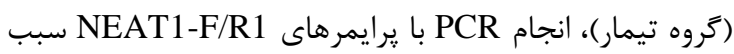

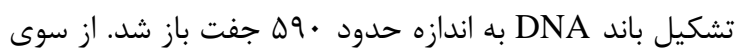

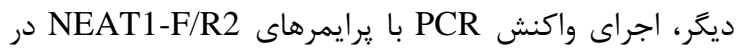

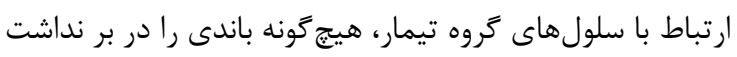

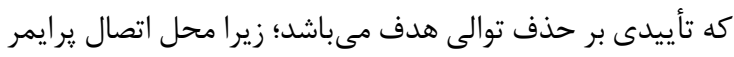

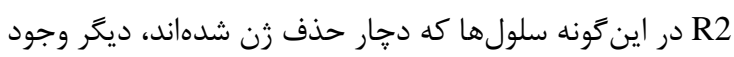

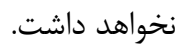
در خصوص سلولهاى تروه كنترل (دريافت كننده وكتور

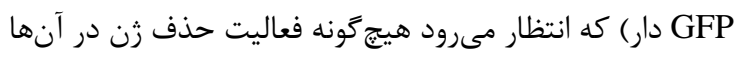

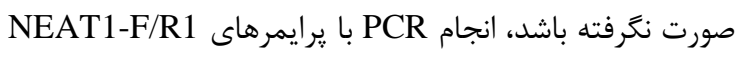

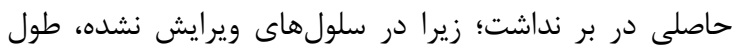

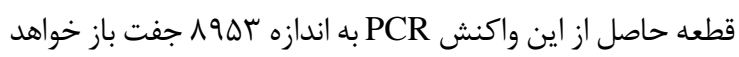

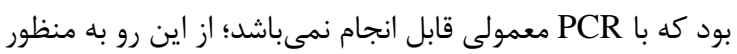

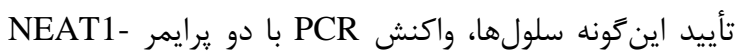

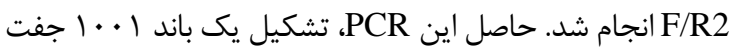
بازى بود كه صحيح است.

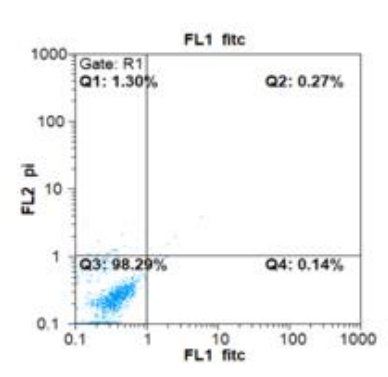

A

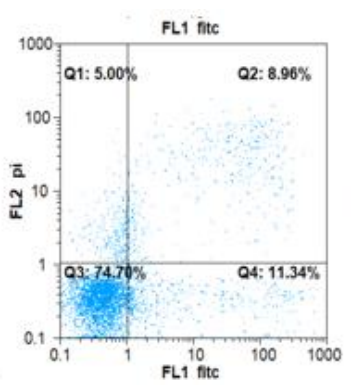

B

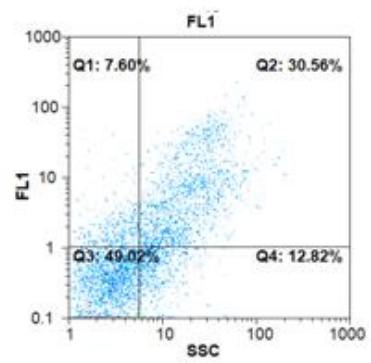

C

شكل ا: نتايج آيويتوز سلولى حاصل از آناليز فلوسيتومترى در سلولهاى

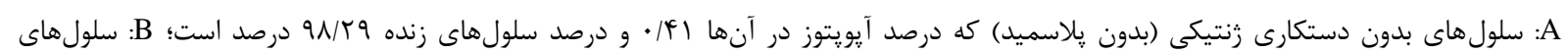

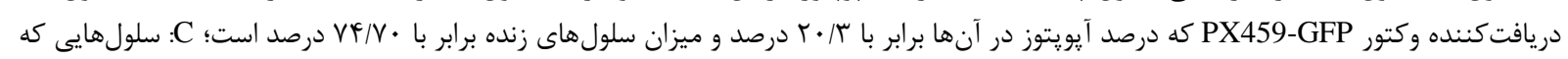

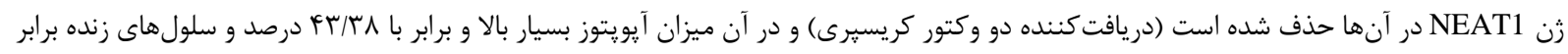

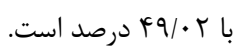

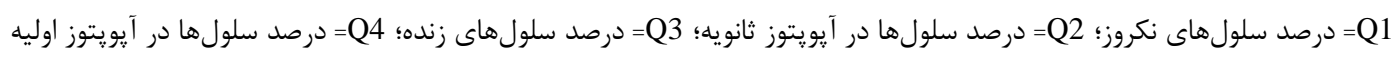


در اين مطالعه كه در ارتباط با رده سلولى سرطان يروستات

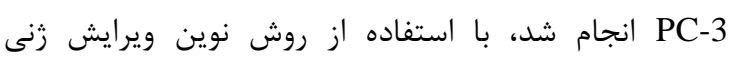
نسبت به حذف بخش بزرگى از RNASPR/Cas9

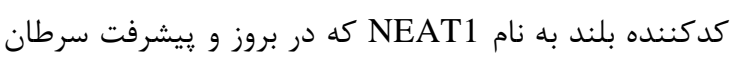

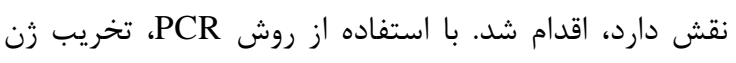
NEAT1 در سلولهاى PC-3 مورد تأييد قرار كرفت. نتايج اين تغيير در زنوم سلول نشاندهنده تغيير در بيان تعدادى از

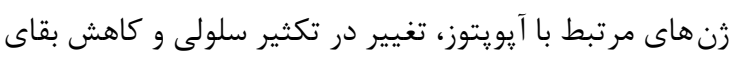

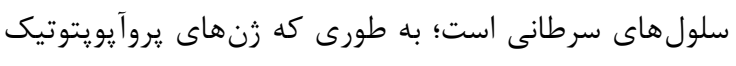

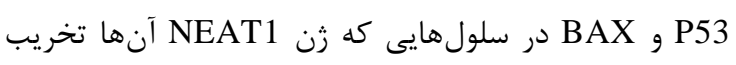
شده بود، نسبت به گروه كنترل افزايش معنادارى را نشان داد.

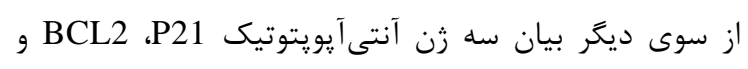
BIRC5

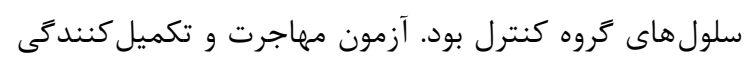

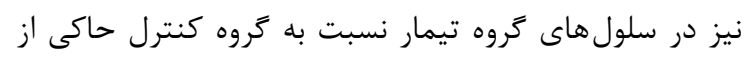

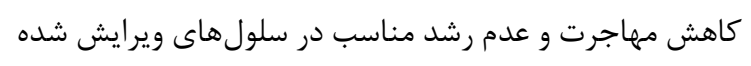

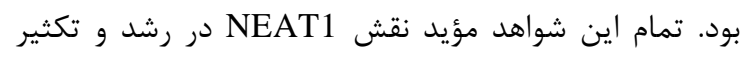

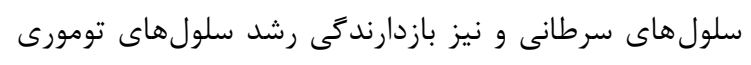

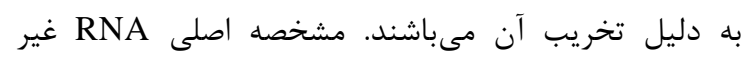

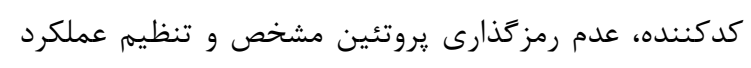

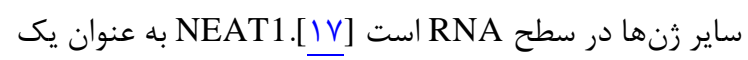
lncRNA

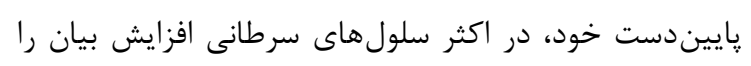

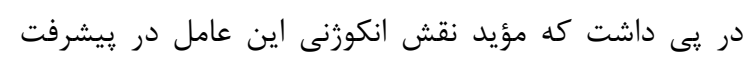

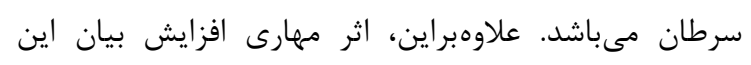

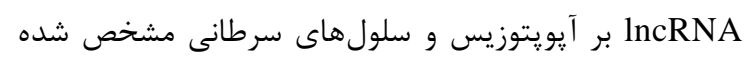

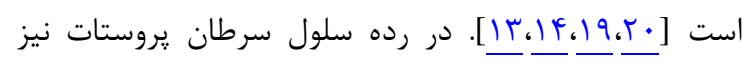

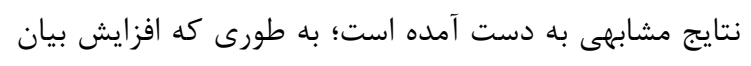
NEAT1

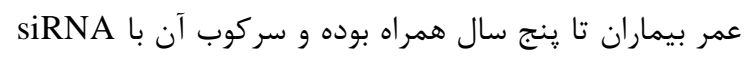

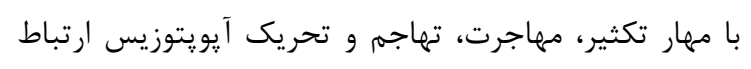

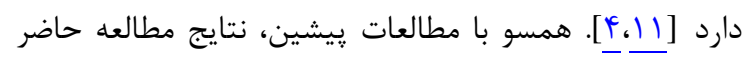

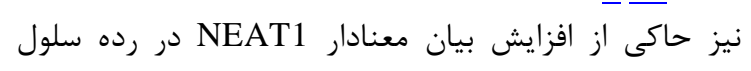

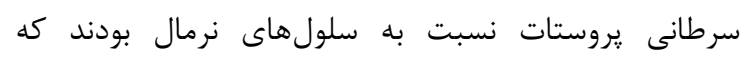
نشان دهنده نقش انكورنى اين عامل در سلول مذكور ميى باشد.

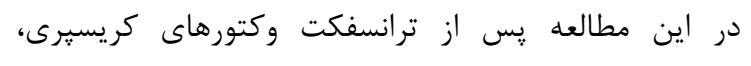

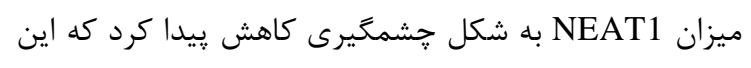

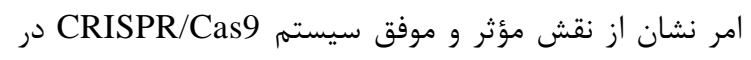

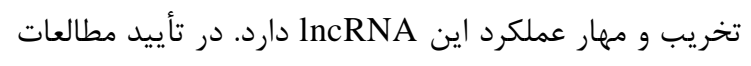

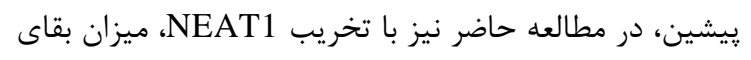

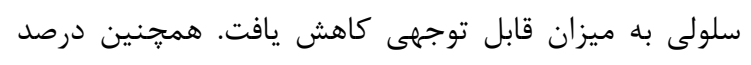

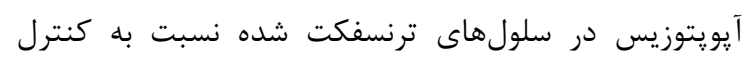
بيشتر شد؛ به صورتى كه در فاز G0/G1، اثر مهارى درى در اين

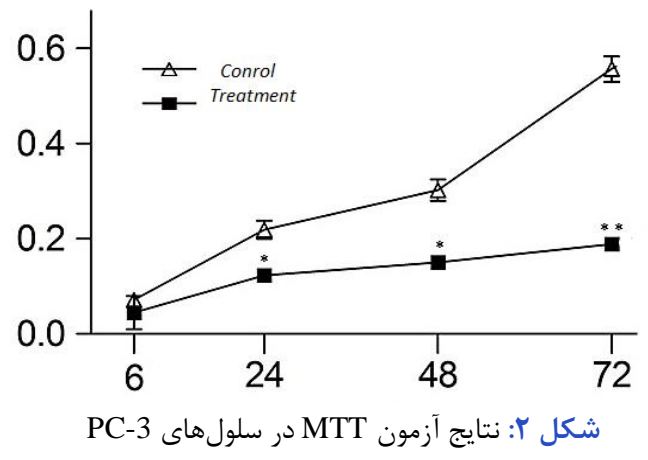

ويرايش زن شده (فاقد زن NEAT1) نسبت به گروه كنترل

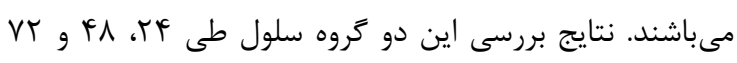

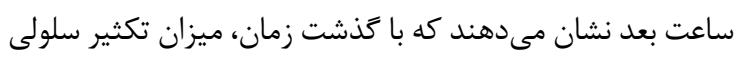

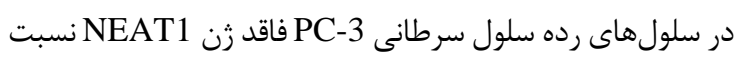
به كروه كنترل كاهش يافته است (شكل بل ب).

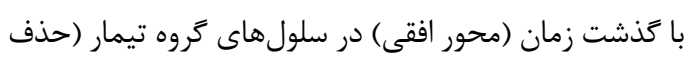

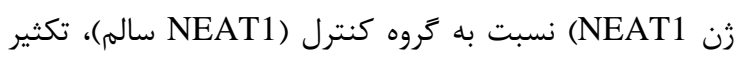
سلولى كاهش يافته است.

\section{نتايج آزمون مهاجرت سلولى}

نتايج آزمون مهاجرت در دو گروه سلول سلول تحت تيمار و گروه

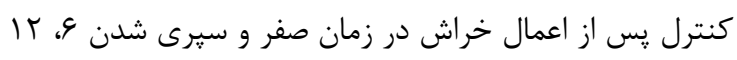

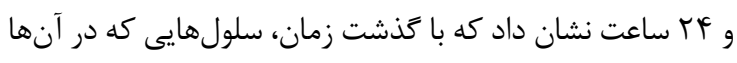

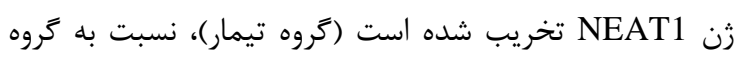

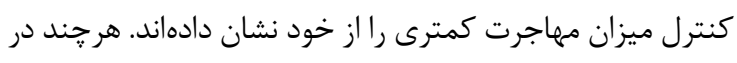

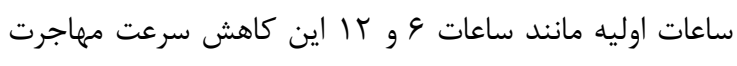

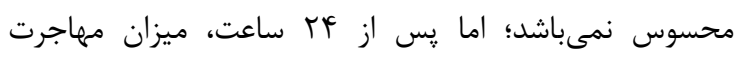

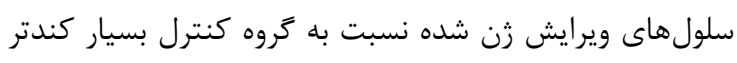

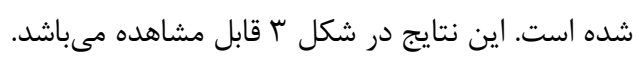

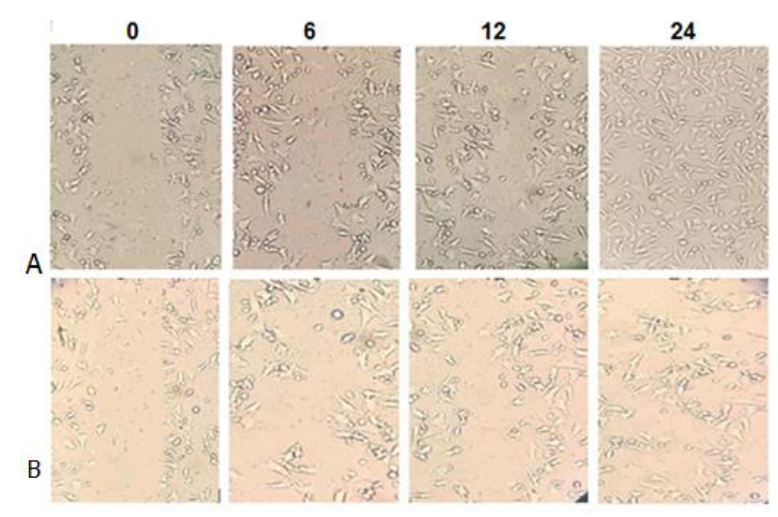

شكل با: رده سلولى PC-3 يس از آزمون خراش و مهاجرت سلولى

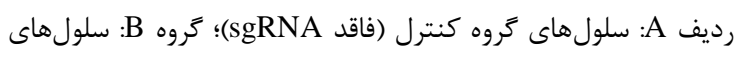

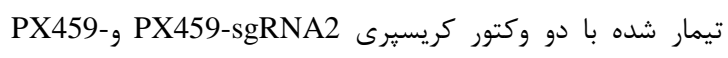

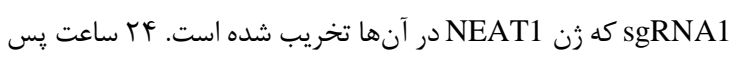

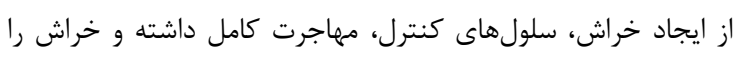

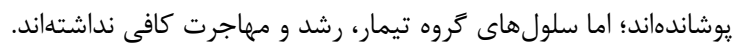


را اعمال كنند. كاهش بيان سه زن P21، BCL2 و BIRC5 و

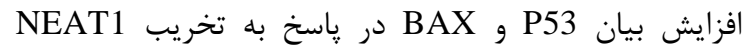

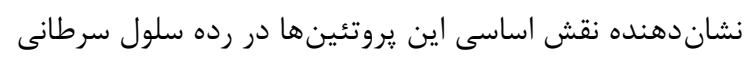

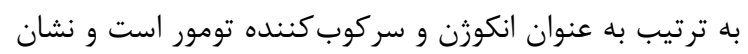

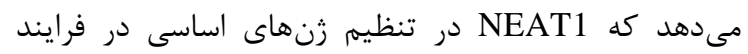

تومورزايى نقش دارد.

\section{نتيجه كيرى}

نتايج مطالعه حاضر نشان دادند كه lncRNA NEAT1 به

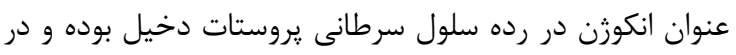

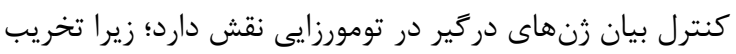

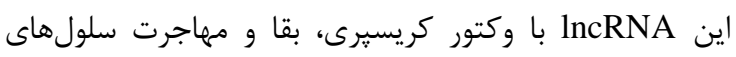

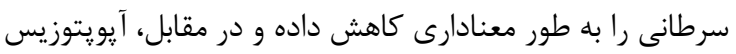

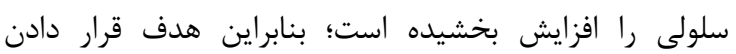

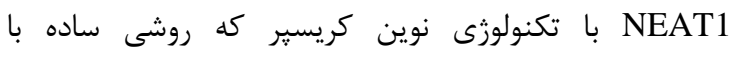
اختصاصيت بالا و مقرون به صرفه است مىتواند در درمان اكثر

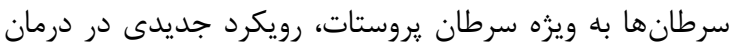

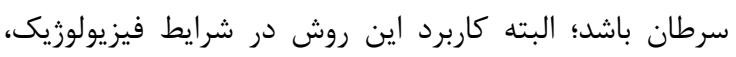

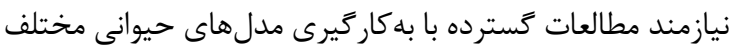

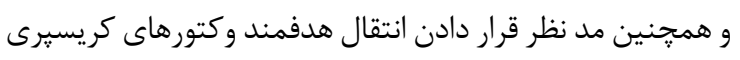
به سلول هاى سرطانى در افراد مبتلا مىباشد. مدرن

\section{تشكر و قدر دانى}

اين مقاله برگرفته از رساله دكترى تخصصى زنتيكى مولكولى دانى

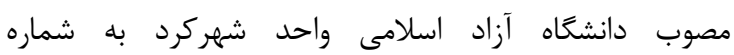

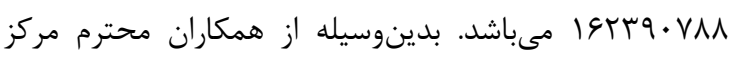

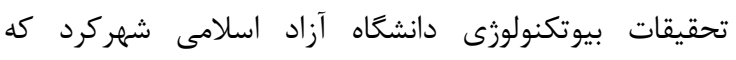

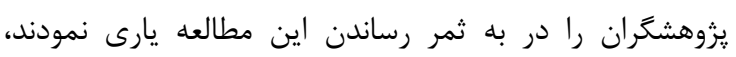
صميمانه تشكر و قدردانى مى

\section{تضاد منافع}

نتايج اين مطالعه با منافع نويسندگان تعارض ندارد.

\section{ملاحظات اخلاقى}

اين يروزه در كميته اخلاق دانشكاه آزاد شهركرد با شناسه

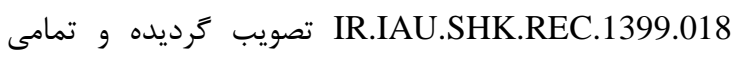
مراحل مطالعه در مورد ردههاى سلولى سرطانى انجام شده است.

\section{سهم نويسندكان}

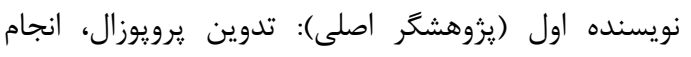

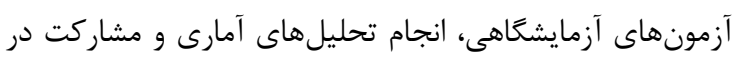

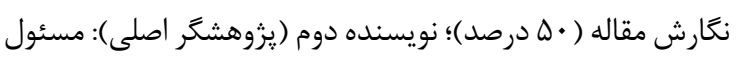

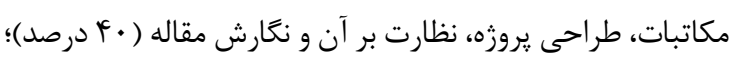

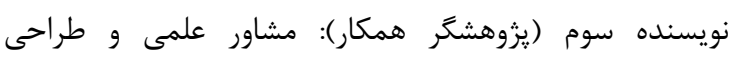

رده سلولى سبب فعال كردن مسير آيويتوزى كرديد.

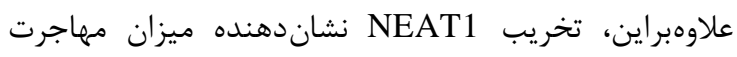

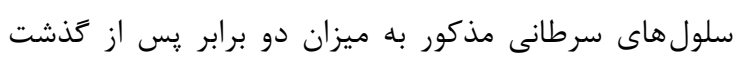

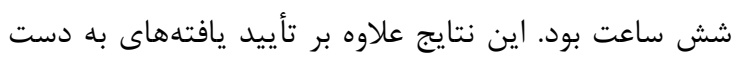

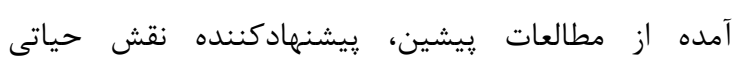
IncRNA NET1 در تنظيم زن هاى وابسته به بقا، آيويتوزيس

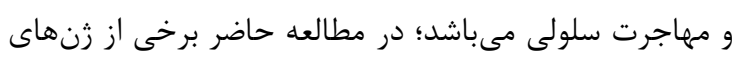

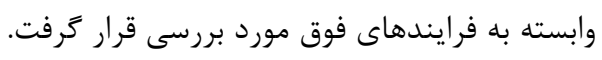

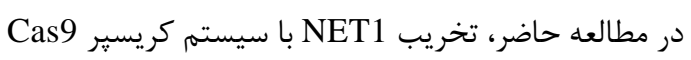

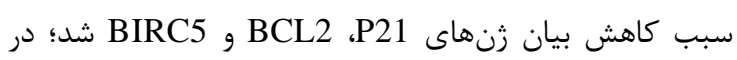

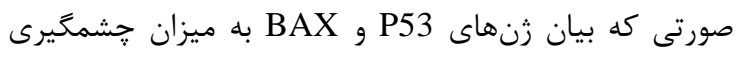

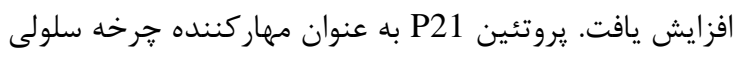

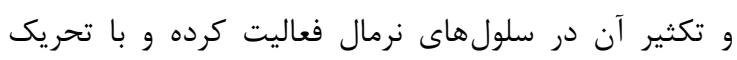

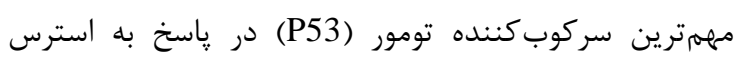

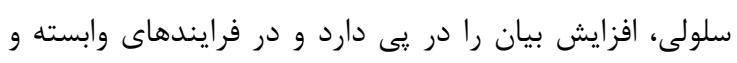

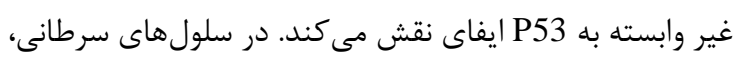

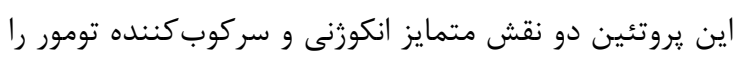

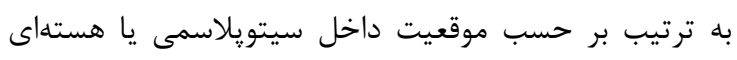

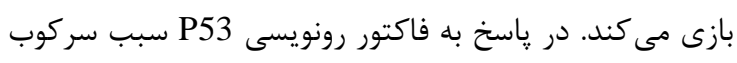

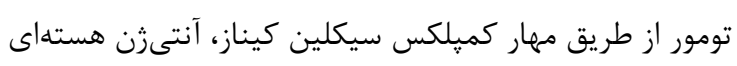

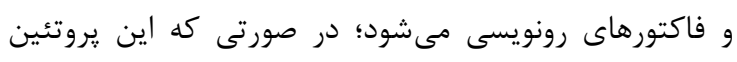

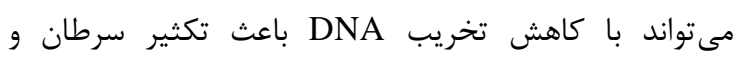

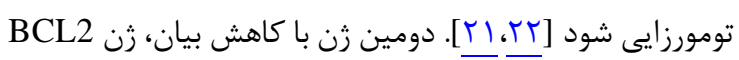

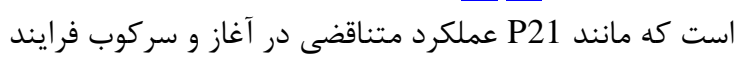

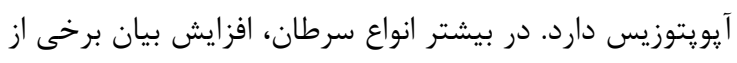

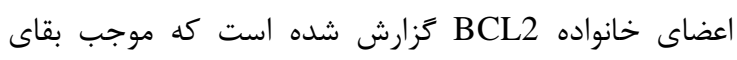

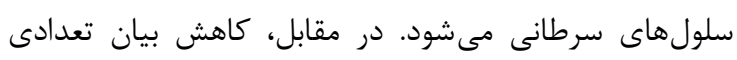

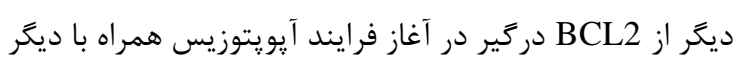

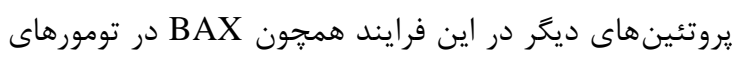

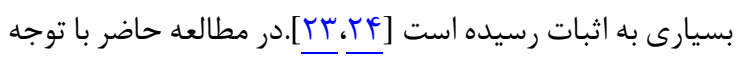

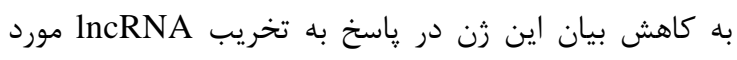

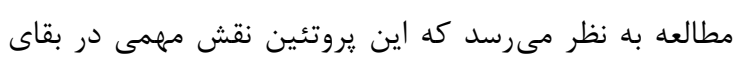

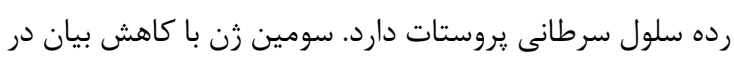

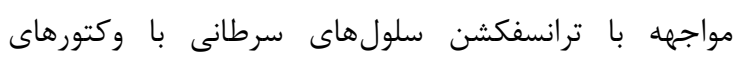

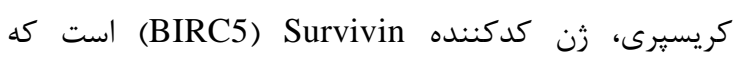

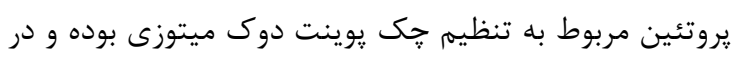

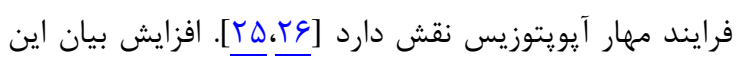

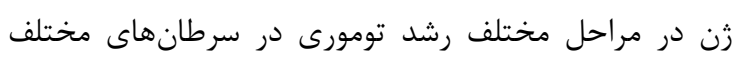

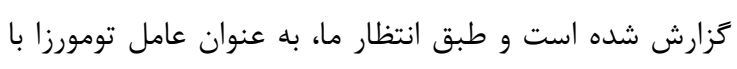

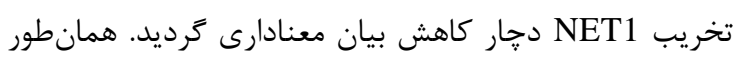

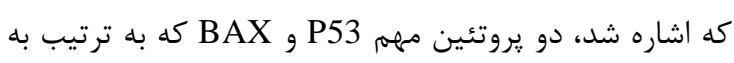

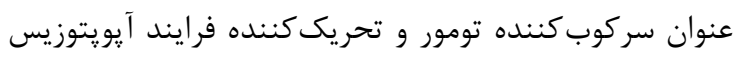

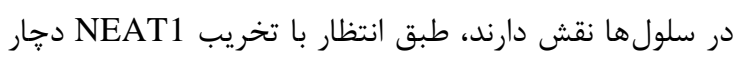

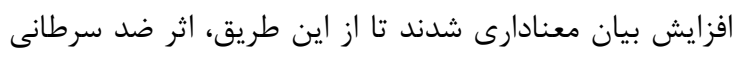




$$
\begin{aligned}
& \text { مركز تحقيقات بيوتكنولوزى دانشعاه آزاد اسلامى شهركرد در }
\end{aligned}
$$

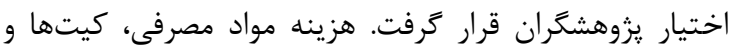

$$
\begin{aligned}
& \text { تجهيزات مصرفى نيز توسط يزوهشگر اول فراهم گرديد. }
\end{aligned}
$$

سازوارههاى زنى (· ( درصد)

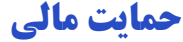 \\ به منظور انجام اين طرح، امكانات و تجهيزات دستخاهى از
}

\section{REFERENCES}

1. Obertova Z, Brown C, Holmes M, Lawrenson R. Prostate cancer incidence and mortality in rural men-a systematic review of the literature. Rural Remote Health. 2012; 12(2):2039-51. PMID: 22616627

2. Rebbeck TR. Prostate cancer genetics: variation by race, ethnicity, and geography. Semin Radiat Oncol. 2017;27(1):3-10. PMID: 27986209 DOI: 10.1016/j.semradonc.2016.08.002

3. Dunn MW. Prostate cancer screening. Semin Oncol Nurs. 2017;33(2):156-64. PMID: 28343840 DOI: 10.1016/j. soncn.2017.02.003

4. Xing Y, Yao R, Zhang Y, Guo C, Jiang S, Xu G, et al. SLERT regulates DDX21 rings associated with Pol I transcription. Cell. 2017;169(4):664-78. PMID: 28475895 DOI: 10.1016/j.cell.2017.04.011

5. Ning L, Li Z, Wei D, Chen H, Yang C. LncRNA, NEAT1 is a prognosis biomarker and regulates cancer progression via epithelial-mesenchymal transition in clear cell renal cell carcinoma. Cancer Biomark. 2017;19(1):75-83. PMID: 28269753 DOI: $10.3233 / C B M-160376$

6. Li P, Huang R, Huang T, Cheng S, Chen Y, Wang Z. Long noncoding RNA NEAT1 promotes proliferation, migration and invasion of human osteosarcoma cells. Int J Med Sci. 2018; 15(11):1227-34. PMID: 30123061 DOI: 10.7150/ijms.25662

7. Fang J, Qiao F, Tu J, Xu J, Ding F, Liu Y, et al. High expression of long non-coding RNA NEAT1 indicates poor prognosis of human cancer. Oncotarget. 2017;8(28):4591827. PMID: 28507281 DOI: $10.18632 /$ oncotarget.17439

8. Fu JW, Kong Y, Sun X. Long noncoding RNA NEAT1 is an unfavorable prognostic factor and regulates migration and invasion in gastric cancer. J Cancer Res Clin Oncol. 2016; 142(7):1571-9. PMID: 27095450 DOI: 10.1007/s00432-0162152-1

9. Wang Z, Zou Q, Song M, Chen J. NEAT1 promotes cell proliferation and invasion in hepatocellular carcinoma by negative regulating miR-613 expression. Biomed Pharmacother. 2017;94:612-18. PMID: 28783584 DOI: 10.1016/j.biopha.2017.07.111

10. Xia TF, Chen J, Wu K, Zhang J, Yan Q. Long noncoding RNA NEAT1 promotes the growth of gastric cancer cells by regulating miR-497-5p/PIK3R1 axis. Eur Rev Med Pharmacol Sci. 2019;23(16):6914-26. PMID: 31486491 DOI: $10.26355 /$ eurrev_201908_18731

11. Wei C, Wang F, Liu W, Zhao W, Yang Y, Li K, et al. CRISPR/Cas9 targeting of the androgen receptor suppresses the growth of LNCaP human prostate cancer cells. Mol Med Rep. 2018;17(2):2901-6. PMID: 29257308 DOI: $10.3892 / \mathrm{mmr} .2017 .8257$

12. Li X, Wang X, Song W, Xu H, Huang R, Wang Y, et al. Oncogenic properties of NEAT1 in prostate cancer cells depend on the CDC5L-AGRN transcriptional regulation circuit. Cancer Res. 2018;78(15):4138-49. PMID: 29871935 DOI: 10.1158/0008-5472.CAN-18-0688

13. Chen B, Deng S, Ge T, Ye M, Yu J, Lin S, et al. Live cell imaging and proteomic profiling of endogenous NEAT1 lncRNA by CRISPR/Cas9-mediated knock-in. Protein Cell. 2020;11(9):641-60. PMID: 32458346 DOI: $10.1007 / \mathrm{s} 13238-$ 020-00706-W

14. Esposito R, Bosch N, Lanzós A, Polidori T, Pulido-Quetglas
C, Johnson R. Hacking the cancer genome: profiling therapeutically actionable long non-coding RNAs using CRISPR-Cas9 screening. Cancer Cell. 2019;35(4):545-57. PMID: 30827888 DOI: 10.1016/j.ccell.2019.01.019

15. Tai Sh, Sun Y, Squires J, Zhang H, Oh W, Liang C, et al. PC3 is a cell line characteristic of prostatic small cell carcinoma. Prostate. 2011;71(15):1668-79. PMID: 21432867 DOI: $10.1002 /$ pros. 21383

16. Ghasemi-Dehkordi P, Doosti A, Jami MS. The functions of azurin of Pseudomonas aeruginosa and human mammaglobin-A on proapoptotic and cell cycle regulatory genes expression in the MCF-7 breast cancer cell line. Saudi J Biol Sci. 2020;27(9):2308-17. PMID: 32884412 DOI: 10.1016/j.sjbs.2020.04.007

17. Abedi S, Doosti A, Jami MS. Evaluation of the preventive and therapeutic effects of a recombinant vector co-expressing prostate-specific stem cell antigen (PSCA) and Clostridium perfringens enterotoxin (CPE) on prostate cancer in rats. Biotechnol Prog. 2020;36(2):e2906. PMID: 31513734 DOI: 10.1002/btpr.2906

18. Wang X, Decker CC, Zechner L, Krstin S, Wink M. In vitro wound healing of tumor cells: inhibition of cell migration by selected cytotoxic alkaloids. BMC Pharmacol Toxicol. 2019;20(1):4-12. PMID: 30626448 DOI: 10.1186/s40360018-0284-4

19. Ma Y, Liu L, Yan F, Wei W, Deng J, Sun J. Enhanced expression of long non-coding RNA NEAT1 is associated with the progression of gastric adenocarcinomas. World $J$ Surg Oncol. 2016;14(1):41-6. PMID: 26911892 DOI: 10.1186/s12957-016-0799-3

20. Yu DJ, Guo CX, Qian J, Li J, Zhu C, Jin X, et al. The long non-coding RNA NEAT1 promotes gastric cancer cell proliferation and invasion by regulating miR103a/STAMBPL1 axis. Technol Cancer Res Treat. 2020; 19:1-8. PMID: 33111649 DOI: 10.1177/1533033820964081

21. Shamloo B, Usluer S. p21 in cancer research. Cancers (Basel). 2019;11(8):1178-97. PMID: 31416295 DOI: $10.3390 /$ cancers 11081178

22. Wu D, Li H, Wang J, Li H, Xiao Q, Zhao X, et al. LncRNA NEAT1 promotes gastric cancer progression via miR1294/AKT1 axis. Open Med. 2020;15(1):1028-38. PMID: 33336058 DOI: $10.1515 / \mathrm{med}-2020-0218$

23. Campbell KJ, Tait SW. Targeting BCL-2 regulated apoptosis in cancer. Open Biol. 2018;8(5):180002. PMID: 29769323 DOI: $10.1098 /$ rsob.180002

24. Li Y, Pan J, Gou M. The anti-proliferation, cycle arrest and apoptotic inducing activity of peperomin $\mathrm{E}$ on prostate cancer PC-3 cell line. Molecules. 2019;24(8):1472. PMID: 30991627 DOI: 10.3390/molecules 24081472

25. Li F, Aljahdali I, Ling X. Cancer therapeutics using survivin BIRC5 as a target: what can we do after over two decades of study? J Exp Clin Cancer Res. 2019;38(1):368. PMID: 31439015 DOI: 10.1186/s13046-019-1362-1

26. Shang X, Liu G, Zhang Y, Tang P, Zhang H, Jiang H, et al. Downregulation of BIRC5 inhibits the migration and invasion of esophageal cancer cells by interacting with the PI3K/Akt signaling pathway. Oncol Lett. 2018;16(3):3373-9. PMID: 30127937 DOI: $10.3892 / \mathrm{ol} .2018 .8986$ 